\title{
Measuring The Performances of the Machines Via Preference Selection Index (PSI) Method and Comparing Them with Values of Overall Equipment Efficiency (OEE)
}

\author{
Emre BİLGIN SARI 1
}

\section{Abstract}

Manufacturing enterprises give importance to determining machine performances in order to manage their operations and prioritize improvement activities. Overall Equipment Efficiency (OEE) is a tool that is frequently used by production managers to examine machine performances and is calculated by considering performance, quality and availability values. However, there are many different criteria that affect the performance of the machines. In this case, a multi-criteria decision-making (MCDM) approach is appropriate for handling machine performance values. The Preference Selection Index (PSI) is a MCDM method that is used for the evaluation of alternatives while weighting the criteria determined. This study was carried out to purpose of using the PSI method to generate the performance index of the machines. In addition to factors used in OEE calculation, MCDM problem with multiple criteria that supported by the literature was developed. The performance ranking of the machines was performed by PSI method with these criteria. The findings of this study suggest that when the more criteria are included in the studies for performance evaluation, the differences in the value of the results can be seen in the closer range and sensitivity. So, it would be useful to implement models that consider different criteria from OEE for machine performance evaluation.

Keywords: Preference Selection Index, PSI, Overall Equipment Efficiency, OEE, MCDM

Jel Codes: M10

\section{Makinelerin Performanslarının Tercih Seçim Endeksi Yöntemi ile Ölçülmesi ve Toplam Ekipman Etkinliği Değerleri ile Karşılaştırılması \\ Özet}

İmalat işletmeleri operasyonlarını yönetmek ve iyileştirme faaliyetlerini önceliklendirmek amacıla makine/ekipman performanslarının belirlenmesine önem vermektedir. Toplam Ekipman Etkinliği (OEE), üretim yöneticilerinin makine performanslarını incelemelerinde sıklıkla kullanılan bir araç olup, performans, kalite ve kullanılabilirlik değerleri göz önünde bulundurularak hesaplanmaktadır. Ancak makinelerin performanslarının etkilendiği farklı ölçütler de mevcuttur. Bu durumda makine performans değerlerinin ele alınması konusunda çok kriterli karar verme problemleri yaklaşımı uygun olmakta ve çözüm sunmaktadır. Tercih Seçim Endeksi (Preference Selection Index / PSI) yöntemi, alternatiflerin değerlendirilmesi için belirlenen kriterleri kendi içinde ağırlıklandıran bir yöntemdir. Bu çalışma, PSI yönteminin makinelerin performans endeksini oluşturmasında kullanılması amacıyla yapılmıştır. OEE hesaplaması sırasında kullanılan, ölçütlerin yanında, literatürce desteklenen faktörler de göz önünde bulundurularak ÇKKV problemi oluşturulmuştur, PSI yöntemi ile makinelerin performans sıralaması yapılmıştır. Bu çalışmanın bulguları, performans değerlendirme çalışmalarına daha fazla kriter dahil edildiğinde, sonuçların değerindeki farklılıkların daha yakın aralıkta ve hassasiyette görülebileceğini göstermektedir. Bu nedenle, makine performansı değerlendirmesi için OEE'den farklı kriterleri de göz önünde bulunduran modelleri uygulamak faydalı olacaktır.

Anahtar Kelimeler: PSI, Toplam Ekipman Etkinliği, OEE, ÇKKV.

Jel Kodu: M10

\section{INTRODUCTION}

In parallel of developing technology, the efforts of the enterprises to increase the production performance are continuing in the current competitive environment. The determination of competition priorities of enterprises causes the necessity of providing higher quality, lower cost and more innovative products. The performance and competitiveness of production enterprises depend on the reliability and efficiency of the production facilities (Madu, 2000: 937; Muchiri, et al., 2011: 295). The performance of production

\footnotetext{
${ }^{1}$ Araş. Gör. Dr., Dokuz Eylül Üniversitesi İktisadi ve İdari Bilimler Fakültesi, İşletme Bölümü, Üretim Yönetimi ve
} Pazarlama Anabilim Dalı, İZMİR EMAIL: emre.bilgin@deu.edu.tr ORCID: 0000-0001-5110-1918 


\section{BILGIN SARI E.}

system can be improved by highlighted the maintenance function (Madu, 1999: 694; Cooke, 2000: 1003 - 1004). Although the production performance of the enterprise is directly related to the rate of equipment use, this is necessary for the production of better quality and lower cost products.

Determination of equipment performance is a process based on many criteria. Overall Equipment Efficiency (OEE) is a frequently used value that makes the performance of the machines clearly understandable. OEE which used to measure the efficiency of equipment in the production area, identifies and measures losses in important aspects of production such as availability, performance and quality ratio (Muchiri, and Pintelon, 2008: 3518). On the other hand, there are many criteria in the literature that can be used to determine and rank equipment (Wang et al., 2000; Samanta et al., 2002; Dağdeviren, 2008; Nguyen, et al., 2016; Ghorabaee, et al., 2018). Since there are many criteria affecting the performance evaluation, multi-criteria decision-making methods can be used to examine machine efficiencies. The Preference Selection Index (PSI) is a multi-criteria decision-making method used by firstly Maniya and Bhatt (2010). PSI provides systematic evaluation without the need for the additional weighting of the criteria.

In this study, it is aimed to calculate machine performances by the PSI method and to compare the results with OEE values of machines. For this purpose, machine performance measurement and especially OEE are explained in the second part of this paper. In addition, literature is given about the other criteria affecting machine performance. In the third part, the PSI method is explained with the application steps. The fourth part of the study is the case study.

\section{MACHINE PERFORMANCE MEASUREMENT}

Production performance of machines in manufacturing enterprises is measured primarily with output unit (Jain et al, 2011:
617). In addition to output, machine performance is also affected by variables such as failure rate and processing time which indicate the result of maintenance (Yan, et al., 2004: 796 - 797). Breakdowns and unrecognized losses in the machines during production cause different negativities, which affects the production performance of them. The method of equipment efficiency improves production performance and provides a smooth working plant.

Overall Equipment Efficiency (OEE) is an efficient method that allows equipment performance measurement (Yaşin \& Daş, 2017: 46). OEE is calculated using the following formula (Muchiri, and Pintelon, 2008: 3520).

OEE $=$ Performance Rate $x$ Quality Rate $x$ Availibility Rate The calculated OEE value can be used at various levels in managing the operations of the enterprise (Dal et al., 2000: 1490). It can be applied to compare the performance of different machines or to compare the previous values of the same machine. The OEE value can also be calculated for the production line, so that line performance can be compared (Sucu et al. 2010: 50). OEE is concerned with the availability of equipment, which is a function of planned and unplanned downtime, and is supported by planning management.

Table 1: Criteria of Equipment Performance

\begin{tabular}{lll}
\hline $\begin{array}{l}\text { Criteria } \\
\text { Indicator }\end{array}$ & Unit & Description \\
\hline $\begin{array}{l}\text { Number of } \\
\text { Failures }\end{array}$ & Number & $\begin{array}{l}\text { Number of operational or } \\
\text { safety failures }\end{array}$ \\
\hline $\begin{array}{l}\text { Failure / } \\
\text { Downtime } \\
\text { frequency }\end{array}$ & $\begin{array}{l}\text { Number / } \\
\text { unit time }\end{array}$ & $\begin{array}{l}\text { Number of failures per } \\
\text { unit time (Reliability } \\
\text { indicator) }\end{array}$ \\
\hline MTBF & Hours & $\begin{array}{l}\text { Mean Time Between } \\
\text { Failures (Reliability } \\
\text { indicator) }\end{array}$ \\
\hline Availability & $\%$ & MTBF / (MTBF+MTTR) \\
\hline OEE & $\%$ & $\begin{array}{l}\text { Availability, Performance } \\
\text { Ratio, Quality Ratio }\end{array}$ \\
\hline
\end{tabular}

Note: (Mean Time to Repair / MTTR)

Source: Muchiri, et al., (2011:300)

Muchiri, et al., (2011: 300) describes the key elements such as the mean time between failures (MTBF) and the number of unplanned maintenance, that should be monitored and 
İzmir İktisat Dergisi (İzmir Journal of Economics) , Yıl: 2019, Cilt:34, Sayı:4, ss. 573-581

controlled after maintenance planning in order to manage equipment performance. The measurement of these performance elements within the OEE framework, the availability of equipment and the development of reliability are considered important. Indicators for equipment performance are shown in Table 1.

To determine of equipment performance in addition to OEE, the use of a different indicators results in the evaluation of this issue as a multicriteria decision making (MCDM) problem and the use of comparing the alternative equipment. In the literature, the studies on this subject are examined; Wang et al., (2000) in the study of the flexible production cell machine selection problem by using the fuzzy MCDM method. In the application for ten alternative machines, the total cost of purchase, total floor area, total number of machines and efficiency criteria were presented. Samanta et al. (2002) used the Analytic Hierarchy Process (AHP) method to make a selection based on seven criteria among five different alternatives. Parida, and Chattopadhyay, (2007) have developed a multi-criteria hierarchical framework for performance measurement in their study. They also explained the availability, performance ratio, quality ratio, number of failures, downtime, and reprocessing rate as equipment performance indicators (Parida, and Chattopadhyay, 2007: 250). Dağdeviren (2008) has implemented an application that integrates AHP and PROMETHEE methods for equipment selection. Nguyen, et al. (2016) evaluated and made selection of conveyor equipment by using the fuzzy AHP and Fuzzy ARAS methods. Ghorabaee et al., (2018) used fuzzy MCDM to evaluate the construction equipment on sustainability.

The PSI method has not previously been used in a study of machine performance. First of all, it is aimed to contribute to the literature by using this method. In addition, the comparison of PSI results with the OEE values commonly used in practice will also contribute to those who want to examine different criteria as well as the OEE value. In this study, the indicators supported in the literature are taken into consideration for multi-criteria machine performance evaluation. And also, to make different view of previous studies, PSI method, which is providing ease of calculation, is used. Previously, the use of the method will be explained and then the case study on this subject is shared.

\section{PREFERENCE SELECTION INDEX (PSI) METHOD}

The Preference Selection Index (PSI) is developed by Maniya and Bhatt (2010) and it is used for multi-criteria decision making (MCDM) the problems. The PSI is explained as a method that stands out due to its feature that determines the weight of the criteria and which does not require relative weighting.

In the PSI method, the overall preference value calculated for each criteria and the preference index $\left(\mathrm{I}_{\mathrm{j}}\right)$ are calculated for each alternative, and the height of the preference index value allows the alternative to be determined as the best (Maniya and Bhatt, 2010: 1786). The use of the PSI method arises in situations where it is difficult to decide the criteria weight (Attri and Grover, 2015: 209).

In the literature, the PSI method is used for ranking or selection of alternatives, and the validity of the method is tested by comparing with the other commonly used methods. Firstly, Maniya and Bhatt (2010) applied the PSI for material selection problem and the results were compared with the outputs obtained by TOPSIS and GTMA methods. Sawant, et al., (2011) in their study used the PSI method for the problem of automatic-oriented vehicle selection, sixteen different vehicle models were ranked based on nine criteria. In the study, for used criteria were desired the maximum and minimum values and the results were compared with the TOPSIS method. Akyüz and Aka (2015) applied PSI method to measure manufacturing performance and evaluated the results using AHP and TOPSIS methods. Mufazzal and Muzakkir (2018) and Noryani et al., (2018), in their studies; PSI was discussed 
with AHP, ANP, DEA, ELECTRE, GRA, GTMA, MAUT, PROMETHEE, SAW, TOPSIS, VIKOR.

Advantage of the PSI method; it is the direct implementation of the alternative to assess the performance of the alternative and to calculate the rating score. On the other hand, the disadvantage is the method that does not allow the user to consider the qualitative factors (Noryani et al., 2018: 3336). This is related to the method based on calculations that determine the weight of criteria within its own systematic.

The steps taken by the Maniya and Bhatt (2010) in PSI method are as follows:

Step-1: Defining the problem and determining the criteria.

Step-2: Rows are the alternatives $A=\left[A_{i}, i=1,2\right.$, $\ldots, n]$, columns are the criteria $C=\left[C_{j}, j=1,2, \ldots\right.$ $, \mathrm{m}]$, and the value of cells $\mathrm{X}_{\mathrm{ij}}$, represent the decision matrix.

Step-3: Normalization of the decision matrix is the standardization of the criteria measured by different units.

The normalization of the criteria in different units is $0-1$, and the reinterpretation of the data to show if the maximum value of the criterion is better, 1 is the best, 0 is the worst, if the minimum value of the criterion is better, 0 is the best, 1 is the worst.

$N_{i j}=\frac{X_{i j}}{X_{i j \max }} ; \forall \mathrm{i}, \mathrm{j} \rightarrow$ if the great value

represents better

$$
N_{i j}=1-\frac{X_{i j}}{X_{i j \max }} \forall \mathrm{i}, \mathrm{j} \rightarrow \text { if the small value }
$$

represents better

Step-4: Calculating preference variation value $\left(\mathrm{PV}_{\mathrm{j}}\right)$.

$$
P V_{j}=\sum_{i=1}^{n}\left[N_{i j}-\overline{N_{j}}\right]^{2}
$$

$\overline{N_{j}}$ : is the average of the normalized values of the alternative $\mathrm{j}$

$$
\overline{N_{j}}=\frac{1}{n} \sum_{i=1}^{n} N_{i j}
$$

Step-5: Determining the overall preference value ${ }^{\psi_{j}}$ for each criteria. For each criteria, the overall preference value deviation $\theta_{j}$ is found. (Quantitative Weighting).

$\theta_{j}=1-P V_{j}$

$\psi_{j}=\frac{\theta_{j}}{\sum_{j=1}^{m} \theta_{j}}$

values of the criteria equals the one $\left(\sum \psi_{j}=1\right)$

Step-6: Calculating the index value.

$\mathrm{I}_{i}=\sum_{j=1}^{m}\left(N_{i j} x \psi_{j}\right)$

The results are accepted as Preference Selection Index (PSI) and are shown as $\mathrm{I}_{\mathrm{i}}$. PSI values are used for alternative selecting, sorting, and comparing, with the highest value showing better.

\section{CASE STUDY}

In this section, the proposed approach is implemented in a manufacturing company operating in Izmir. The company produces a speed of $200 \mathrm{pcs} / \mathrm{min}$ (machine speed depending on the part form) on multi-station machines that make mass production with cold forming method. The data regarding the equipment performances of the enterprises which produce at such a speed is obtained by examining the OEE values of the machines. However, the maintenance and production managers of the enterprise have found that there are different indicators effective in determining machine performances other than 
İzmir İktisat Dergisi (İzmir Journal of Economics) , Yll: 2019, Cilt:34, Sayı:4, ss. 573-581

OEE values. In order to manage the performance improvement studies on the machines, it is required to compare the machines. In this case, there is a need for a MCDM method to compare machines. For this purpose, the calculation of preference index values of machines by using PSI method is studied.

\section{Data Source}

In implementation, it is necessary to identify the equipment for performance comparison. In this direction, the enterprise provided 10 alternative machines. Then the criteria for equipment comparison are determined as supported by literature and provided by the manufacturing. From the performance measurement literature, equipment related performance indicators are listed as; availability, production rate, quality, number of stops, number of downtime and rework rate (Kutucuoglu, et al., 2001: 181; Parida, and Chattopadhyay, 2007: 250). This study aims to measure the equipment performance and also compare it with the OEE values so, OEE indicators are taken account as criteria near the literature supported and there are no rework data gathering by company in cold forming manufacturing type so that this indicator is not seen as a criterion.

Table 2: Decision Matrix

\begin{tabular}{|c|c|c|c|c|c|c|c|}
\hline $\begin{array}{l}\text { Criterion / } \\
\text { Alternative }\end{array}$ & 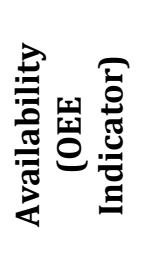 & 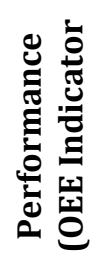 & 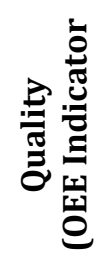 & 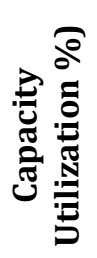 & 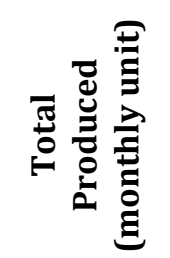 & 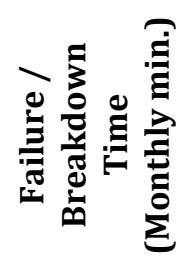 & 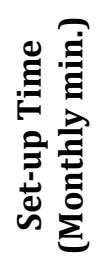 \\
\hline Goal & $\max$ & $\max$ & $\max$ & $\max$ & $\max$ & $\min$ & $\min$ \\
\hline M1 & 90.5 & 100.0 & 100.0 & 27.5 & 1.750 .068 & 11 & 1000 \\
\hline M2 & 85.2 & 100.0 & 100.0 & 22.6 & 1.222 .914 & 43 & 1234 \\
\hline M3 & 80.9 & 97.0 & 100.0 & 54.1 & 2.922 .654 & 137 & 4232 \\
\hline M4 & 76.6 & 97.4 & 100.0 & 48.4 & 2.033 .653 & 141 & 4526 \\
\hline M5 & 70.8 & 99.8 & 100.0 & 48.3 & 2.136 .516 & 483 & 5129 \\
\hline M6 & 69.4 & 99.1 & 100.0 & 7.9 & 320.290 & 30 & 913 \\
\hline M7 & 76.9 & 86.3 & 100.0 & 54.4 & 1.553 .541 & 1097 & 3755 \\
\hline M8 & 67.3 & 96.1 & 100.0 & 60.2 & 2.700 .152 & 167 & 7826 \\
\hline M9 & 62.2 & 97.8 & 100.0 & 45.7 & 1.819 .885 & 295 & 6765 \\
\hline M10 & 58.5 & 99.7 & 100.0 & 53.8 & 2.113 .653 & 185 & 9000 \\
\hline
\end{tabular}

Table 3: Normalized Decision Matrix

\begin{tabular}{|c|c|c|c|c|c|c|c|}
\hline $\begin{array}{l}\text { Criterion / } \\
\text { Alternative }\end{array}$ & 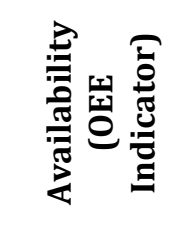 & 莞 & 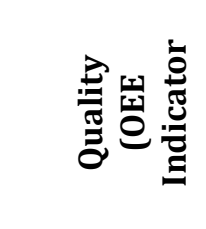 & 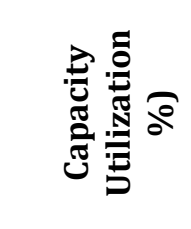 & 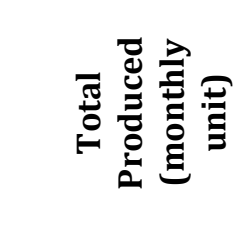 & 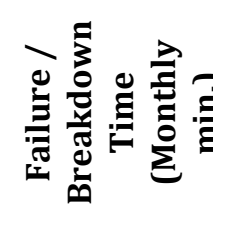 & 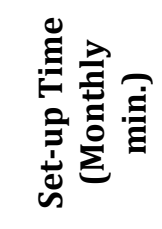 \\
\hline M1 & 1.000 & 1.000 & 1.000 & 0.457 & 0.599 & 0.990 & 0.889 \\
\hline M2 & 0.941 & 1.000 & 1.000 & 0.375 & 0.418 & 0.961 & 0.863 \\
\hline M3 & 0.894 & 0.970 & 1.000 & 0.899 & 1.000 & 0.875 & 0.530 \\
\hline M4 & 0.846 & 0.974 & 1.000 & 0.804 & 0.696 & 0.871 & 0.497 \\
\hline M5 & 0.782 & 0.998 & 1.000 & 0.802 & 0.731 & 0.560 & 0.430 \\
\hline M6 & 0.767 & 0.991 & 1.000 & 0.131 & 0.110 & 0.973 & 0.899 \\
\hline M7 & 0.850 & 0.863 & 1.000 & 0.904 & 0.532 & 0.000 & 0.583 \\
\hline M8 & 0.744 & 0.961 & 1.000 & 1.000 & 0.924 & 0.848 & 0.130 \\
\hline M9 & 0.687 & 0.978 & 1.000 & 0.759 & 0.623 & 0.731 & 0.248 \\
\hline M10 & 0.646 & 0.997 & 1.000 & 0.894 & 0.723 & 0.831 & 0.000 \\
\hline$\overline{N_{j}}$ & 0.816 & 0.973 & 1.000 & 0.702 & 0.635 & 0.764 & 0.507 \\
\hline
\end{tabular}


Table 4: Overall Preference Value

\begin{tabular}{|c|c|c|c|c|c|c|c|}
\hline $\begin{array}{l}\text { Criterion / } \\
\text { Alternative }\end{array}$ & 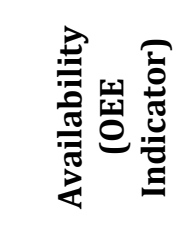 & 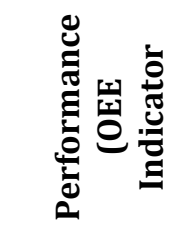 & 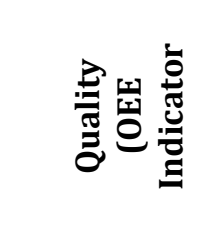 & 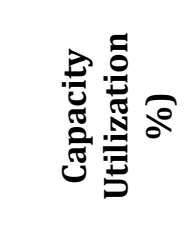 & 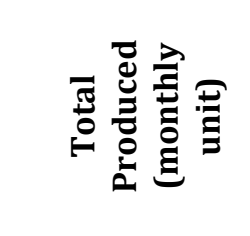 & 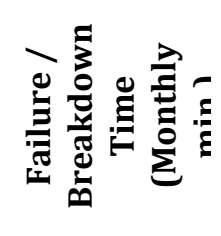 & 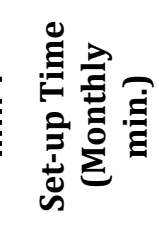 \\
\hline M1 & 0.034 & 0.001 & 0.000 & 0.060 & 0.001 & 0.051 & 0.146 \\
\hline M2 & 0.016 & 0.001 & 0.000 & 0.107 & 0.047 & 0.039 & 0.127 \\
\hline M3 & 0.006 & 0.000 & 0.000 & 0.038 & 0.133 & 0.012 & 0.001 \\
\hline M4 & 0.001 & 0.000 & 0.000 & 0.010 & 0.004 & 0.012 & 0.000 \\
\hline M5 & 0.001 & 0.001 & 0.000 & 0.010 & 0.009 & 0.042 & 0.006 \\
\hline M6 & 0.002 & 0.000 & 0.000 & 0.326 & 0.277 & 0.044 & 0.153 \\
\hline M7 & 0.001 & 0.012 & 0.000 & 0.040 & 0.011 & 0.584 & 0.006 \\
\hline M8 & 0.005 & 0.000 & 0.000 & 0.089 & 0.083 & 0.007 & 0.142 \\
\hline M9 & 0.017 & 0.000 & 0.000 & 0.003 & 0.000 & 0.001 & 0.067 \\
\hline M10 & 0.029 & 0.001 & 0.000 & 0.037 & 0.008 & 0.005 & 0.257 \\
\hline $\mathbf{P} \mathbf{V}_{\mathbf{j}}$ & 0.112 & 0.015 & 0.000 & 0.721 & 0.572 & 0.795 & 0.904 \\
\hline $\mathbf{Q}_{\mathbf{j}}$ & 0.888 & 0.985 & 1.000 & 0.279 & 0.428 & 0.205 & 0.096 \\
\hline$\psi_{j}$ & 0.229 & 0.254 & 0.258 & 0.072 & 0.110 & 0.053 & 0.025 \\
\hline
\end{tabular}

There are seven criteria that are taken into consideration in the comparison of equipment, so that three of these criteria are the values used in OEE calculation. The decision matrix created with the alternative equipment and criteria determined are given in Table 2 .

In this study, the quality criteria are 100 for all the alternatives, and this criterion is not change the PSI ranking. The reason of being a criterion in the decision matrix is that the quality criterion is an OEE indicator and the PSI results will be compared with the OEE values at the end of the application.

\section{PSI Calculations}

After the decision matrix is formed in the PSI method, a normalized decision matrix is formed to standardize the values. Table 3 shows the normalized decision matrix and shows the values.

Following the creation of a normalized decision matrix, it is necessary to find the preference variance and to determine the overall preference value. Overall preference value can be considered as benchmark weights. Table 4 shows the overall preference value calculation step.

When the overall preference values that determined for each criterion, were examined, the highest weight was given to the Quality indicator with a value of 0.222 . The second most significant weight is given to the Performance indicator with a value of 0.207 . These two criteria with the highest weight are the values used for the OEE calculation. As a result of the overall preference value for each criterion, the values accepted as the PSI for each alternative are calculated. Table 5 shows the calculation of PSI values.

When the preference index values calculated by PSI method are examined, it is seen that M3 machine has the highest value and M1 and M4 machines are followed. After comparing the performance of machines with OEE values, to investigate whether the effect highest criteria weights of quality and performance, PSI method was applied over the remaining four criteria, without including OEE indicators. Performance ranking of the 10 machines considered as an alternative was calculated by taking into consideration the capacity utilization, total 
produced, breakdown time and set-up time. preference values and the monthly OEE values of Table 6 was established to compare the PSI the machines.

Table 5: Calculation of the PSI Values

\begin{tabular}{|c|c|c|c|c|c|c|c|c|}
\hline $\begin{array}{l}\text { Criterion / } \\
\text { Alternative }\end{array}$ & 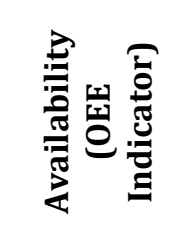 & 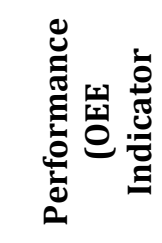 & 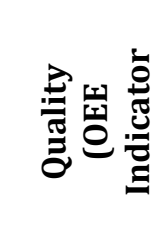 & 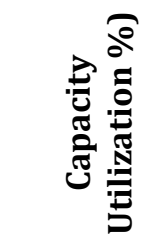 & 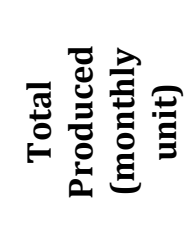 & 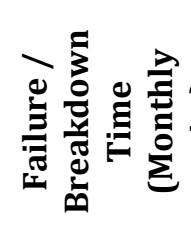 & 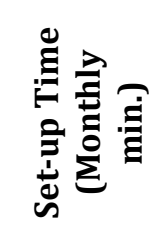 & $\bar{n}$ \\
\hline M1 & 0.229 & 0.254 & 0.258 & 0.033 & 0.066 & 0.052 & 0.022 & 0.913 \\
\hline M2 & 0.215 & 0.254 & 0.258 & 0.027 & 0.046 & 0.051 & 0.021 & 0.872 \\
\hline M3 & 0.205 & 0.246 & 0.258 & 0.065 & 0.110 & 0.046 & 0.013 & 0.943 \\
\hline M4 & 0.194 & 0.247 & 0.258 & 0.058 & 0.077 & 0.046 & 0.012 & 0.891 \\
\hline M5 & 0.179 & 0.253 & 0.258 & 0.058 & 0.081 & 0.030 & 0.011 & 0.868 \\
\hline M6 & 0.176 & 0.252 & 0.258 & 0.009 & 0.012 & 0.051 & 0.022 & 0.780 \\
\hline M7 & 0.195 & 0.219 & 0.258 & 0.065 & 0.059 & 0.000 & 0.014 & 0.809 \\
\hline M8 & 0.170 & 0.244 & 0.258 & 0.072 & 0.102 & 0.045 & 0.003 & 0.893 \\
\hline M9 & 0.157 & 0.248 & 0.258 & 0.055 & 0.069 & 0.039 & 0.006 & 0.831 \\
\hline M10 & 0.148 & 0.253 & 0.258 & 0.064 & 0.080 & 0.044 & 0.000 & 0.846 \\
\hline
\end{tabular}

Table 6: Comparison of OEE Values of Machines with PSI Values

\begin{tabular}{cccc}
\hline Machine & OEE & PSI I & PSI II \\
\hline M1 & $90.4 \%$ & $91.3 \%$ & $66.7 \%$ \\
M2 & $85.2 \%$ & $87.2 \%$ & $55.9 \%$ \\
M3 & $78.4 \%$ & $94.3 \%$ & $90.2 \%$ \\
M4 & $74.6 \%$ & $89.1 \%$ & $74.2 \%$ \\
M5 & $70.6 \%$ & $86.8 \%$ & $68.7 \%$ \\
M6 & $68.8 \%$ & $78.0 \%$ & $36.6 \%$ \\
M7 & $66.4 \%$ & $80.9 \%$ & $53.1 \%$ \\
M8 & $64.7 \%$ & $89.3 \%$ & $85.4 \%$ \\
M9 & $60.9 \%$ & $83.1 \%$ & $64.7 \%$ \\
M10 & $58.3 \%$ & $84.6 \%$ & $72.3 \%$ \\
\hline
\end{tabular}

As seen in Table 6, M1 has the highest OEE value with $90.4 \%$, while the PSI method based on seven criteria (PSI I) is in the second preference and PSI method based on four criteria (PSI II) is in the sixth preference. On the other hand, M3, which has the highest preference value according to the indices as PSI I and PSI II, ranks third in terms of OEE value. Further, the preference values of the alternatives for the seven criteria ranged from 0.943 to 0.780 , while the preference values of the alternatives for the four criteria ranged from 0.902 to 0.366 . The increase in openness between these values shows that the differences between the machines become more evident as the results move away from the OEE indicators.

\section{CONCLUSION}

Changing in customer requirements, increasing competition conditions and low-cost demand, force the businesses to review the efficiency of their operations. Businesses follow machine performances in order to eliminate production losses and to manage improvement works correctly. OEE is a frequently used measurement instrument in the industry for machine accomplishment. However, there are many different indicators to evaluate machine performances. In this instance, the MCDM methods can be used to estimate the performance of the machines. The PSI is a method which is based on the variance of preference with its systematic calculation steps. In this study, machine performance values were found by the PSI method and compared with monthly OEE values of machines.

During the implementation of the PSI method, seven criteria for the ranking of ten alternative machines were discussed. Three of these criteria are availability, performance and quality ratios used in the calculation of OEE value. These OEE included criteria are thought as they will play a 


\section{BILGIN SARI E.}

decisive role. But there is no any proof for other criteria for comparison with OEE values. For that reason, there are two scenarios in implementation. First of them is all seven criteria which are included in OEE is also is taken account and the preference values of machines reached as a result of application were named as PSI I. For other scenario, another MCDM model was established in which the indicators used in the calculation of the OEE value were not included and PSI II are reached. PSI II values were first compared with OEE values of machines and then with PSI I results.

In the PSI I application, the range of preference values of alternatives varies with narrow range of preference values of alternatives in the PSI II application. The difference between these values shows that the differences in preference are more pronounced in measurements based on fewer criteria. As the number of criteria increases, the selection values of the alternatives approach each other, but also small changes become more decisive. In the comparison of the results with the OEE values, it was observed that the results obtained by PSI I method, which included the OEE indicators, were more similar to the OEE values ranking, but not exactly the same.

This study closes a literature gap in terms of using the PSI method for the first time in evaluating machine performance. In addition, this study differs from other studies which applied PSI method and compared with the other MCDM methods, while comparing the results obtained by the PSI method with the OEE values of the machines. In order to improve this study, the criteria weights that are inherent in the PSI method can be calculated by using with the other MCDM methods. And it could be compared with weights found by other weighting methods.

\section{REFERENCES}

Akyüz, G., and Aka, S. (2015). İmalat Performansı Ölçümü için Alternatif Bir Yaklaşım: Tercih Indeksi (PSI) Yöntemi. Business and Economics Research Journal, 6(1), 63.

Attri, R., and Grover, S. (2015). Application of Preference Selection Index Method for Decision Making over The Design Stage of Production System Life Cycle. Journal of King Saud University-Engineering Sciences, 27(2), 207216.

Cooke, F.L. (2000). Implementing TPM in Plant Maintenance: Some Organizational Barriers. International Journal of Quality \& Reliability Management, 17 (9), 1003-1016.

Dağdeviren, M. (2008). Decision Making in Equipment Selection: An Integrated Approach with AHP and PROMETHEE. Journal of Intelligent Manufacturing, 19(4), 397-406.

Dal B., Tugwell P., and Greatbanks R., (2000). Overall Equipment Effectiveness as a Measure of Operational Improvement - a Practical Analysis. International Journal of Operations \& Production Management, 20 (12), 1488-1502.

Ghorabaee, M. K., Amiri, M., Zavadskas, E. K., and Antucheviciene, J. (2018). A New Hybrid Fuzzy MCDM Approach for Evaluation of Construction Equipment with Sustainability Considerations. Archives of Civil and Mechanical Engineering, 18(1), 32-49.

Jain, S., Triantis, K. P., and Liu, S. (2011). Manufacturing Performance Measurement and Target Setting: A Data Envelopment Analysis Approach. European Journal of Operational Research, 214(3), 616-626.

Kutucuoglu, K. Y., Hamali, J., Irani, Z., \& Sharp, J. M. (2001). A framework for managing maintenance using performance measurement systems. International Journal of Operations \& Production Management, 21(1/2), 173-195.

Madu, C. (2000). Competing Through Maintenance Strategies. International Journal 
İzmir İktisat Dergisi (İzmir Journal of Economics) , Yıl: 2019, Cilt:34, Sayı:4, ss. 573-581

of Quality \& Reliability Management 17(9), 937-948.

Madu, C. (1999). Reliability \& Quality Interface, International Journal of Quality \& Reliability Management, 16(7), 691-698.

Maniya, K. and Bhatt, M.G. (2010). A Selection of Material Using a Novel Type Decision-Making Method: Preference Selection Index Method. Materials and Design, 31, 1785-1789.

Muchiri, P., and Pintelon, L. (2008). Performance Measurement Using Overall Equipment Effectiveness (OEE): Literature Review and Practical Application Discussion. International Journal of Production Research, 46(13), 3517-3535.

Muchiri, P., Pintelon, L., Gelders, L., and Martin, H. (2011). Development of Maintenance Function Performance Measurement Framework and Indicators. International Journal of Production Economics, 131(1), 295302.

Mufazzal, S., and Muzakkir, S. M. (2018). A New Multi-Criterion Decision Making (MCDM) Method Based On Proximity Indexed Value for Minimizing Rank Reversals. Computers \& Industrial Engineering, 119, 427-438.

Nguyen, H. T., Dawal, S. Z. M., Nukman, Y., Rifai, A. P., and Aoyama, H. (2016). An Integrated MCDM Model for Conveyor Equipment Evaluation and Selection in an FMC Based on A Fuzzy AHP and Fuzzy ARAS in The Presence of Vagueness. PloS one, 11(4), 1 - 26.

Noryani, M. I., Sapuan, S. M., and Mastura, M. T. (2018). Multi-Criteria Decision-Making Tools for Material Selection of Natural Fibre Composites: A Review. Journal of Mechanical
Engineering and Sciences Malaysia, 12(1), 3330-3353.

Parida, A. and Chattopadhyay, G. (2007). Development of A Multi-Criteria Hierarchical Framework for Maintenance Performance Measurement (MPM). Journal of Quality in Maintenance Engineering, 13(3), 241-258,

Samanta, B., Sarkar, B., and Mukherjee, S. K. (2002). Selection of Opencast Mining Equipment by A Multi-Criteria Decision-Making Process. Mining Technology, 111(2), 136-142.

Sawant, V. B., Mohite, S. S., and Patil, J. (2011), A Decision-Making Framework Using a Preference Selection Index Method for Automated Guided Vehicle Selection Problem. International Conference on Technology Systems and Management (ICTSM) (12-16).

Sucu A., Atasoy, E., and Temiz, İ. (2010). Toplam Ekipman Etkinliği ve Bir Uygulama. Dokuz Eylül Üniversitesi Sosyal Bilimler Enstitüsü Dergisi, 12(4), 49-60.

Wang, T. Y., Shaw, C. F., and Chen, Y. L. (2000). Machine Selection in Flexible Manufacturing Cell: A Fuzzy Multiple Attribute DecisionMaking Approach. International Journal of Production Research, 38(9), 2079-2097.

Yan, J., Koc, M., and Lee, J. (2004). A Prognostic Algorithm for Machine Performance Assessment and Its Application. Production Planning \& Control, 15(8), 796-801.

Yaşin, M. F., and Daş, G. S. (2017). KOBI'lerde Ekipman Etkinliğinin İyileștirilmesinde TEE Tabanlı Yeni Bir Yaklașım: Bir Ahșap İșleme Kuruluşunda Uygulama. Journal of the Faculty of Engineering \& Architecture of Gazi University, 32(1), 45 - 52. 